$\underline{\text { Research Articles }}$

\title{
Napa Green: Funding Nonprofit Social Ventures in Crisis
}

\author{
Hannah DeYoung' \\ 1 Sonoma State University \\ Keywords: social venture funding, social entrepreneurship, social venture, nonprofit, sustainability, wine business, wine, wine industry, coronavirus, \\ napa valley, sustainability certification, non-profit, non-profit fundraising
}

https://doi.org/10.26813/001c.22077

\section{Wine Business Journal}

Vol. 4, Issue 2, 2020

Napa Green, a regional vineyard and winery sustainability certification program, is in its first year transitioning out from under the umbrella of its parent company, the Napa Valley Vintners (NVV). Napa Green was fully funded by the NVV as a way to help their members achieve compliance with the local, statewide, and national environmental regulations. However, the NVV sought to create a program that would one day be its own independent nonprofit. At the beginning of 2020, the NVV began stepping down their funding to Napa Green with the hopes that the organization could be fully funded on its own by 2022. Anna Brittain, the executive director of Napa Green, began seeking out funding sources to get the organization to financial independence as soon as possible. With the Coronavirus pandemic having serious impacts on the U.S. economy, forcing many businesses to close or rethink the way they operate, Napa Green was forced to completely rework its business plan to secure funding, as well as find a way to continue fulfilling the organization's mission with limited resources.

It was nine o'clock in the morning on a sunny, April day in 2020, but the downtown streets in Napa, California, were silent. Where cars and people usually hummed along through their daily routine, only a stray cat remained. The vibrant Main Street retail businesses, wine tasting rooms, and restaurants had been all but shuttered. An office door read "Sustainable Napa County," but the interior was vacant.

Just a month earlier, Napa Green Executive Director Anna Brittain and Program Assistant Meagan Scott prepared for yet another busy day running the region's vineyard and winery sustainability certification program. They had a new online portal for their members to finalize, as well as marketing and events to finish planning for later in the year. A long list had been made of potential revenue streams to pursue in the coming months. They would soon leave to visit a local winery and discuss the benefits of enrolling in the program. Twenty-twenty was their first year as an independent nonprofit, and they were determined to make the sustainability program itself, self-sufficient

Nevertheless, since the COVID-19 pandemic had hit the United States in mid-March and Napa County went under a shelter-in-place order, their plans for the year had been thrown into chaos. The local wineries they worked with were all closed and the future of both the region and the organization was uncertain. With many of their 2020 strategies now impossible to implement, they needed a new plan for financial success, and they needed it now.

Anna and Megan needed to reassess their business plan for the year to find new ways to remain financially solvent. It was impossible to say how long the stay-at-home orders would last, and the region would continue to be impacted by a sharp decrease in tourism. As companies nationwide slashed budgets to stay in business, the Napa Valley Vintners (NVV), their main source of funding, could cut or pull Napa Green's future funding. Increasingly, nonprofit organizations needed to create commercial sources of income since government funding for such ventures was rare and unpredictable, and Napa Green was no exception (Weerawardena et al., 2010). They needed to prove that they had a plan for becoming financially independent as soon as possible, or risk losing it all.

\section{LITERATURE REVIEW}

Non-profit organizations were facing increasingly challenging operational environments in the face of scarce government funding, driving many to adopt commercial practices for survival (Weerawardena et al., 2010). By doing so they took on elements of multiple organizational forms, becoming a unique hybrid organization in the process. These hybrid organizational forms were often referred to as social purpose organizations (Barraket et al., 2016) or social enterprises (Powell et al., 2018) which trade in order to fulfil their social mission. The business model of integrated hybrid organizations were only possible because of the organization's dual mission, and its core activities were simultaneously both commercial and social. Thus, the beneficiaries were both the customers and the world at large (Ebrahim et al., 2014). Cheah et al. (2019) defined a social enterprise as "an [organization] that has a clear social or environmental mission, adopts market-based approaches to pursue a self-sustaining revenue model, and allocates significant resources or profit distribution to fulfil its social or environmental mission." Social enterprises must be meticulously designed to achieve both social and commercial objectives (Moizer \& Tracey, 2010). Due to the delicate need 
to balance both social and commercial objectives, strategic planning and operations could become increasingly difficult. Many refer to needing to achieve a double or triple bottom line-meaning social enterprises must fulfill their mission while staying profitable enough to be able to continue their work (Szymańska \& Jegers, 2016).

Is the business model of social purpose organizations viable? Most research suggests the business models of social enterprises can be viable, but they must perform the daunting task of realizing their social mission while running a profitable business. During the earlier stages, the organization must focus on reinvesting its profits in order to realize its social mission, and only later should it retain profits for strategic investments (Szymańska \& Jegers, 2016). Social and community enterprises like Napa Green could become self-sustaining, and indeed could create social and economic change through vibrant organizations (Chell, 2007). In order to achieve both social goals and financial sustainability social enterprises must rely on diverse income streams which strengthen financial viability and reduce reliance on service-level agreements and grants (Powell et al., 2018). This study describes the challenges faced by Napa Green at the onset of the COVID-19 pandemic to shed light on alternative ways in which social enterprises can become viable and self-sustainable.

\section{AN INDUSTRY DRIVEN TO CHANGE}

\section{Environmental issues and the wine industry}

Why should wineries have a sustainability certification at all? The Napa Green model sought to help local producers reduce their impact on the environment, achieve compliance with local regulations, and better navigate the threat of climate change. Because grape growers tended to an especially sensitive agricultural product, they were acutely aware of the threat of climate change and had been noting significant shifts in weather patterns since the 1990s (Asimov, 2019). Some regions, such as England, had warmed enough to allow for the significant and consistent production of quality cool climate grapes like Pinot Noir, Chardonnay, and Pinot Meunier for the purpose of sparkling wine production (Asimov, 2019). On the other hand, wine regions that were prized for their climate like the famed Napa Valley, had experienced increased uncertainty in their growing conditions (Bauman et al., 2020). Napa Valley, as well as the greater North Coast region, have seen a number of record wildfires in recent years, partially attributed to climate change producing hotter and drier summer. Altitudes which were before inhospitable quickly became desirable (Asimov, 2019). Napa Valley itself had seen a number of record wildfires in recent years, partially attributed to climate change producing hotter and drier summers (Mulkern, 2020).
Growers were rapidly testing new farming strategies, like row orientation and canopy management, to minimize sun impact and slow ripening. In Bordeaux, previously outlawed grapes, such as Touriga Nacional and Albariño, were now being planted, as traditional grape varieties struggled in the rising temperatures (Asimov, 2019). Extreme weather events were becoming more common worldwide, and the industry braced itself for the years to come (Asimov, 2019). Technological advancements had been made both in vineyards and wineries to lessen the need for human labor as well as decrease the number of organic and inorganic materials needed. For instance, new machines could save both time, energy, and water to do the same tasks as in years past and made farming without chemical inputs more manageable (Koch, 2020).

In the United States, the federal government and Trump administration had repealed a number of environmental protection laws, putting the responsibility for climate action instead on business owners and consumers (Jotzo et al., 2018). As both growers and consumers sought solutions to mitigate climate change, the term organic gained traction, but individuals like Anna worried the organic certification was not impactful enough. ${ }^{1}$ Organic focused only on the farming system and eliminating the use of synthetic pesticides, whereas sustainable winegrowing encompassed environmental stewardship and resource efficiency elements both in the vineyard and winery, as well as broader topics including social equity and business resilience.

\section{Vineyard and winery sustainability certifications landscape}

In recent years both consumers and producers had become increasingly interested in wine produced in an environmentally friendly way (Gallenti et al., 2019; Sirieix \& Remaud, 2010). As one way to navigate this, numerous labelling and certification systems had been created to guarantee environmentally friendly production (Gallenti et al., 2019). These new sustainability certifications and labels played a variety of roles within the larger market: they conveyed useful information to help consumers identify more sustainable wines, increased product trustworthiness, and educated more consumers about the different meanings of sustainability (Sogari et al., 2016).

As Exhibit 1 illustrates, while there were a number of other vineyard-specific sustainability certifications at the time, Napa Green was the only one which addressed the unique needs of winegrowers in Napa County. Other winegrowing certifications emphasized minimal farming inputs but often neglected other ways winegrowers and producers could reduce their environmental impact. Very few certifications (besides Napa Green) addressed concerns regarding

\footnotetext{
1 In the United States the term “organic” is regulated by the U.S. Department of Agriculture (USDA). For farm or business to be certified organic, they must comply with USDA regulations, submit an application and pay certification fees, as well as pass an on-site inspection. For a product to be labeled as organic, it must be produced without excluded methods (i.e., genetic engineering) and only use allowed substances. In the case of wine, this excludes sulfur dioxide which inhibits many U.S. producers from labeling their wines as organic. Up to $100 \mathrm{ppm}$ of sulfur dioxide however is allowed if the wine is labeled instead as "Made with organically grown grapes" to indicate the vineyard source was organic, even though the winemaking process means the final product cannot be classified as such. Source: U.S. Department of Agriculture, n.d.
} 


\begin{tabular}{|c|c|c|c|}
\hline Certification & Certifying Body & Notes & Logo \\
\hline Biodynamic & U.S. Demeter Association & $\begin{array}{l}\text { Views whole estate as an ecosystem, follows } \\
\text { moon cycles for vineyard and winery work, no } \\
\text { synthetic pesticides or fertilizers. }\end{array}$ & \\
\hline $\begin{array}{l}\text { Certified California } \\
\text { Sustainable } \\
\text { Winegrowing } \\
\text { (CCSW) }\end{array}$ & $\begin{array}{l}\text { California Sustainable } \\
\text { Winegrowing Alliance }\end{array}$ & $\begin{array}{l}\text { Either vineyard, winery or both certifications, } \\
\text { including multiple aspects of winery operations } \\
\text { as they relate to sustainability. }\end{array}$ & \\
\hline Lodi Rules & $\begin{array}{l}\text { Lodi Rules Sustainable } \\
\text { Winegrowing Program }\end{array}$ & $\begin{array}{l}\text { 100+ sustainability standards plus a Pesticide } \\
\text { Environmental Assessment System (PEAS), } \\
\text { examining the impact pesticides have on } \\
\text { workers and the vineyard's ecosystem. }\end{array}$ & \\
\hline $\begin{array}{l}\text { Long Island } \\
\text { Sustainable } \\
\text { Winegrowing (LISW) }\end{array}$ & $\begin{array}{l}\text { Long Island Sustainable } \\
\text { Winegrowing Inc. }\end{array}$ & $\begin{array}{l}\text { Tailored the VineBalance program from } \\
\text { Cornell University to the region specifically. } \\
\text { Features third-party certification. }\end{array}$ & \\
\hline $\begin{array}{l}\text { Low Input Viticulture } \\
\text { and Enology (LIVE) } \\
\text { Certified }\end{array}$ & Live, Inc. & $\begin{array}{l}\text { Based on international standards of Integrated } \\
\text { Production by a group of viticulturalists, } \\
\text { winemakers, university researchers, and } \\
\text { environmental partners, sent to the IOBC for } \\
\text { accreditation. }\end{array}$ & \\
\hline Napa Green & Napa Valley Vintners & $\begin{array}{l}\text { Both vineyard and winery certifications } \\
\text { available, tailored to region, including } \\
\text { independent audits, consultants, marketing } \\
\text { support, and workshops. }\end{array}$ & \\
\hline Organic & $\begin{array}{l}\text { United States Department } \\
\text { of Agriculture (USDA) }\end{array}$ & $\begin{array}{l}\text { Limits use of synthetic products, no added } \\
\text { sulfur, three-year transition process. "Made } \\
\text { with Organic Grapes," can use non-organic } \\
\text { yeast and sulfites. }\end{array}$ & \\
\hline $\begin{array}{l}\text { SIP Certified } \\
\text { (Sustainability in } \\
\text { Practice) }\end{array}$ & SIP Certified & $\begin{array}{l}\text { Includes a larger array of both labor and } \\
\text { agricultural practices for sustainable } \\
\text { certification. }\end{array}$ & \\
\hline $\begin{array}{l}\text { Sonoma County } \\
\text { Sustainable }\end{array}$ & $\begin{array}{l}\text { CCSW/Fish Friendly } \\
\text { Farming/Lodi Rules/SIP }\end{array}$ & $\begin{array}{l}\text { Recognizes certified sustainable practices } \\
\text { through a number of third-party programs, } \\
\text { including: CCSW, Fish Friendly Farming, Lodi } \\
\text { Rules, and SIP. }\end{array}$ & \\
\hline
\end{tabular}

\section{Exhibit 1: U.S. Sustainable Winegrowing Certifications}

Source: Compiled by case author from searches of websites for the listed associations.

sustainable practices in the winery, and even fewer had seen widespread adoption.

In addition to the programs focused on winegrowing, wineries began using other sustainability certifications intended for a wider audience. Some examples of this, included: Leadership in Energy and Environmental Design (LEED), the Certified B Corporation (B Corp) program, and the Living Building Challenge. Each served a variety of purposes-the B Corp program, for instance, helped wineries strive for environmental and social change, while the LEED and Living Building Challenges guided the winery building processes to create more environmentally friendly structures (Clarke, 2019). Regionally, other ventures like the Cal- ifornia Green Business Network (formerly the Green Business Program) sought to help small-to-medium-sized businesses implement better environmental practices.

While these programs all served a purpose, it was worth noting that consumers were easily confused by the many variations of sustainable labelling, and some even doubted the trustworthiness of "green" claims (Forbes et al., 2009). Certification programs proved a useful tool for producers seeking better environmental and social performance but had a long way to go before they could be widely appreciated by consumers. 


\section{Regional context}

Although Napa Valley accounted for only four percent of California's wine production, its significance nationally and internationally extended far beyond its market share (Napa Valley Vintners, 2019). Viticulture had existed in the valley since 1839, with a boom in production and the beginnings of acclaim in the 1880s (Mohan, 2014). However, both phylloxera in the 1890s and prohibition in the 1920s had devastating impacts on the wine industry in the region. Only in the 1960s, when the vines planted after World War II matured, did the region once again start to show promise (Mohan, 2014). It was not until the Paris Wine Tasting of 1976, where French judges ranked Napa wines higher than their French counterparts in a blind tasting, that the region started to receive international acclaim (Taber, 2005). Since then, the number of wineries had grown from a few dozen to several hundred (Napa Valley Vintners, 2020).

Napa Valley had become a hub for world-class winemaking, and wine lovers from far and wide traveled to experience it and taste the famous wines themselves. By late 2010, the tourism industry was booming, welcoming 3.85 million visitors in 2018 and generating USD 2.23 billion, nearly 70 percent of which came from overnight hotel stays by visiting tourists. While the number of visitors in 2018 had only increased 8.9 percent from 2016, direct visitor spending was up 15.9 percent (Visit Napa Valley, 2020).

\section{NAPA GREEN: ESTABLISHING AN INDEPENDENT NONPROFIT}

The Napa Valley Vintners had originally founded and funded Napa Green in the early 2000s to help local wineries establish better environmental practices and remain in compliance with regional regulations.

\section{The catalyst}

In 1990, the Napa River was declared an impaired body of water by the California Regional Water Quality Control Board, San Francisco Bay Region (Water Board) due to evidence of widespread erosion and concern over local fish and wildlife (Napolitano et al., 2007). In order to help improve the quality, the Water Board imposed a total maximum daily load and new regulations specific to vineyard owners since grape growing was the primary agricultural use in the valley. To try and help growers maintain compliance with these new regulations, local interest groups and nonprofits worked on solutions. The various groups wanted to help growers be in compliance and also be good environmental stewards.

In 1999, the Fish Friendly Farming program, founded by Laurel Marcus, started providing such support to growers in Sonoma County. ${ }^{2}$ Local stakeholders, including the Napa Valley Vintners, Napa County Resource Conservation District, Napa Valley Grapegrowers, and Sierra Club, saw its success and were ready for something similar to be tailored to the Napa Valley. In 2002, the Napa Valley Vintners partnered with Fish Friendly Farming to create the Napa Green Land program. The first Napa Green Land certification was in established 2004. Initially grower costs were minimal as grants covered the Fish Friendly Farming program.

At the time, even just staying compliant with the strict local regulations in Napa required a high level of organization, time, effort, and attention to detail. Napa Green became the Napa Valley Vintners' way to step in and help their grower and winery members meet and exceed compliance. A challenge many of them faced was the ability to manage sustainability goals while also staying afloat in a highly competitive market. As Michelle Novi of the Napa Valley Vintners explained:

A lot of these wineries [were] pretty small and had a small staff. Everybody kind of [had] to be a jack-ofall-trades and sometimes there just [wasn't] the bandwidth. We [had] someone on staff to help through every step of the process. ${ }^{3}$

However, the NVV never intended to be the sole "owner" of the program indefinitely. They believed that a sustainability organization should be able to fully sustain itself for the best chance at long-term success. While they had been willing to use their resources to get the program started, they established Napa Green as its own nonprofit in August 2019 and planned to gradually reduce their funding from fiscal year 2020-2022. Exhibit 2 details Napa Green's journey to independent nonprofit.

\section{Two programs, one goal}

Napa Green's mission was to, "Serve as a catalyst and facilitator to grow certified sustainable, responsible businesses committed to environmental stewardship and climate action in Napa County." As of 2020, the organization's goals were focused on engaging strategic economic sectors, playing a pivotal role in county climate action, providing meaningful value to the community, and exemplifying the values of sustainability. See Exhibit 3 for further details of Napa Green's mission and vision.

\footnotetext{
2 Fish Friendly Farming (FFF) is a certification program for agricultural properties managed to restore fish and wildlife habitat and improve water quality. The program is run by the California Land Stewardship Institute, a non-profit organization located in Napa County, California. Fish Friendly Farming offers farmers access to expertise on such problems as erosion and soil loss, stream bank failure, and water quality degradation. Implementation of this through the FFF program not only benefits the environment, but also represents a cost-effective and efficient management strategy. In addition, the program serves as a means of implementing the requirements of several adopted TMDL (Total Maximum Daily Load) in the counties of Napa, Sonoma, and Mendocino, meaning that Fish Friendly Farming-certified sites are compliant with TMDL regulations. The regulations are part of state and federal water quality laws and for these counties focus on reducing the amount of fine sediment entering creeks and rivers and on reducing stream water temperatures. Source: Fish Friendly Farming, n.d.

3 Lutz, 2018; Interview of Michelle Novi, by Hannah DeYoung on March 13, 2020.
} 


\section{Certification}

Napa Green offered two distinct, but complementary, certifications: Napa Green Certified Land and Napa Green Certified Winery.

The Napa Green Certified Land program helped growers and vineyard managers create holistic conservation farm plans, including not only the vineyards but also the roads and land connecting to waterways to protect the watershed (North Bay Business Journal, 2020b). As part of the Land certification, members developed a farm plan, which was audited before receiving certification. Vineyards had to be recertified every five years. Exhibit 4 provides details on Napa Green's Land certification process. The certification functioned as an umbrella program, recognizing two regional third-party certification pathways-the California Land Stewardship Institute's Fish Friendly Farming program as well as the Napa County Resource Conservation District's LandSmart program. ${ }^{4}$

Officially launched in 2008, the Napa Green Winery certification program was independently created and managed by the NVV with the help of Anna Brittain and John Garn of ViewCraft, a small consulting firm specializing in sustainable winegrowing. Napa Green worked with wineries to put together an action plan, including any outstanding items which were required for certification as well as others they could work toward for continual improvement. With the action plan finalized, Napa Green then connected the wineries with a third-party certifier-the Napa County representative for the California Green Business Network. Once their practices were verified and wineries certified, there would be an onsite recertification process every three years. Additionally, Napa Green established an annual "desk audit" to get an update from the wineries on their metrics and action plan.

Highly customized to local wineries' specific needs, it was one of the first certifications in the world that not only considered environmental management in the vineyard but also winery operations. Anna explained, "A lot of people tend to think about sustainability only in the vineyard or agricultural side and not make that translation to how important sustainability is on the production, hospitality, and administration side." ${ }^{5}$ More than 100 sustainability best practices had to be met for a winery to be certified, with recertification occurring every three years (Lutz, 2018). Exhibit $\mathbf{5}$ details the Napa Green Winery certification process.

\section{Milestones}

In 2015, the Napa Valley Vintners set a goal to have all of their members participating in one or both Napa Green certification programs by 2020 but had no dedicated staff
The Journey to

Independent

Non-Profit

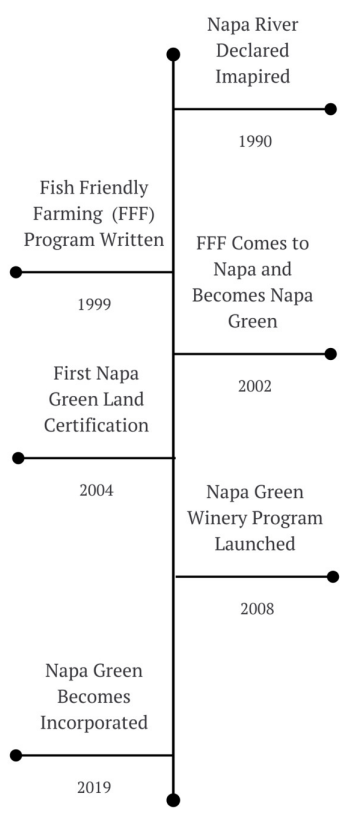

Exhibit 2: Napa Green Timeline

Sources: Information provided by Fish Friendly Farming and Anna Brittain, Napa Green.

\section{MISSION AND VISION \\ Napa Green serves as a catalyst and facilitator to grow certified sustainable, \\ (o Napa County. \\ Our Goals: \\ To engage with strategic economic sectors to promote and facilitate integration of onscientious, green business standards and a commitment to continuing improvement. These rigorous practice- and performance-based sustainability standards, customized for each business sector, are independently validated by third-party certifiers. \\ To play a pivotal role in achieving county climate action and emissions reduction goals. \\ To provide meaningful feedback on sustainability performance and serve as an educator and convener to inspire the community and marketplace with the benefits and achievements of responsible green businesses. \\ To stand as a leader exemplifying that sustainability elevates health, quality and experience for employees, customers and community, now and in the future. \\ Our Values: \\ Leadership, Stewardship, Authenticity, Collaboration, Impact, Resilience, Regeneration}

Exhibit 3: Napa Green Mission, Vision, Goals, and Values

Source: Anna Brittain, Napa Green

member to drive this initiative forward. To achieve this

\footnotetext{
4 For information on Fish Friendly Farming, see footnote 2; LandSmart is a regional collaborative program that helps land managers meet their natural resource management goals while supporting productive lands and thriving streams. LandSmart was developed by the Sonoma Resource Conservation District (RCD), Napa County RCD, Mendocino County RCD, and Gold Ridge RCD in collaboration with the USDA Natural Resources Conservation Service (NRCS), land managers, and environmental agencies. Source: LandSmart, n.d.

5 All quotes in this case except where noted are based on field interviews with Anna Brittain and Meagan Scott, by Hannah DeYoung in early March 2020.
} 

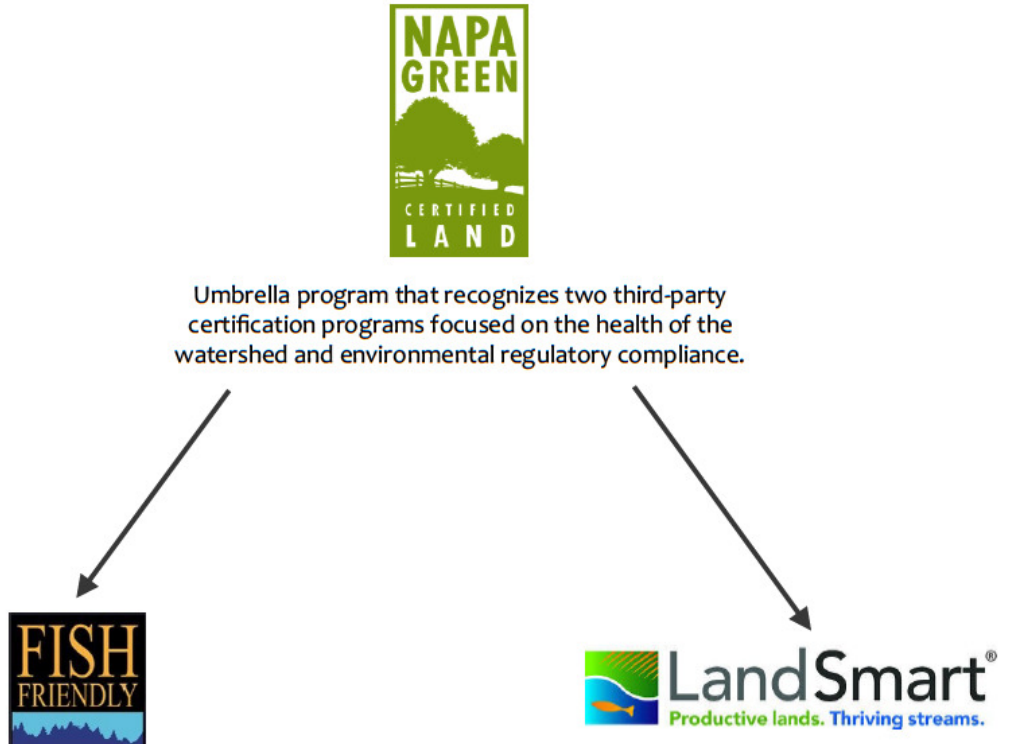

Program managed by the Napa County Resource Conservation District.

To be recognized as Napa Green Certified develop whole property Farm Plan and complete elements on Water Conservation, Habitat Preservation and Social Equity.

Development of custom Farm Plan for the whole property - includes beyond compliance elements for Water Use and Social Equity.

Farm Plans third-party certified by representatives from the Napa County Agricultural Commissioner's Office and Farm Plans third-party certified by representatives from the Napa Certified Erosion Control Experts from County Agricultural Commissioner's sister RCDs.

Office and the National Marine Fisheries Service.

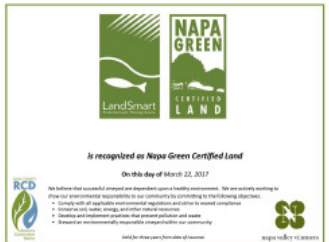

Whole-farm certification issued by both FFF/LandSmart and Napa Green Certified Land.

Signs available to share certification.

Napa Green Certified Land logo can be used on the bottle if at least $95 \%$ of the grapes are sourced from certified vineyards in the Napa Valley.

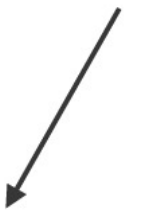

\section{Exhibit 4: Napa Green Land Certification Process}

milestone, they brought back ViewCraft to consult on the program and support new members as they worked toward their 2020 goal. Additionally, ViewCraft assisted with outreach and the start-to-finish facilitation of Napa Green Winery enrollment and certification. Both the Napa Valley Vintners and ViewCraft continued to promote participation in the Napa Green Land program and answered questions about the certification process via Fish Friendly Farming or LandSmart.

In 2016, Napa Green launched an important new element of the Winery certification-an "Integrated Resource $\mathrm{Au}$ dit," which would act as a one-stop energy, water, and waste assessment. This audit analyzed each winery's energy and water use as well as waste diversion. In doing so, they established baseline resource metrics to track improvements over time and helped their consulting engineer recommend specific actions to both meet and exceed program requirements.

Their work had not gone unnoticed: In November 2018, the Napa Valley Vintners and the Napa Green Program were awarded the Governor's Environmental and Economic Leadership Award, California's highest environmental honor (Lutz, 2018).

Anna had consulted on the Napa Green program from 2015 to 2019 and was officially hired on as the executive director in October 2019 to lead the newly formed nonprofit 


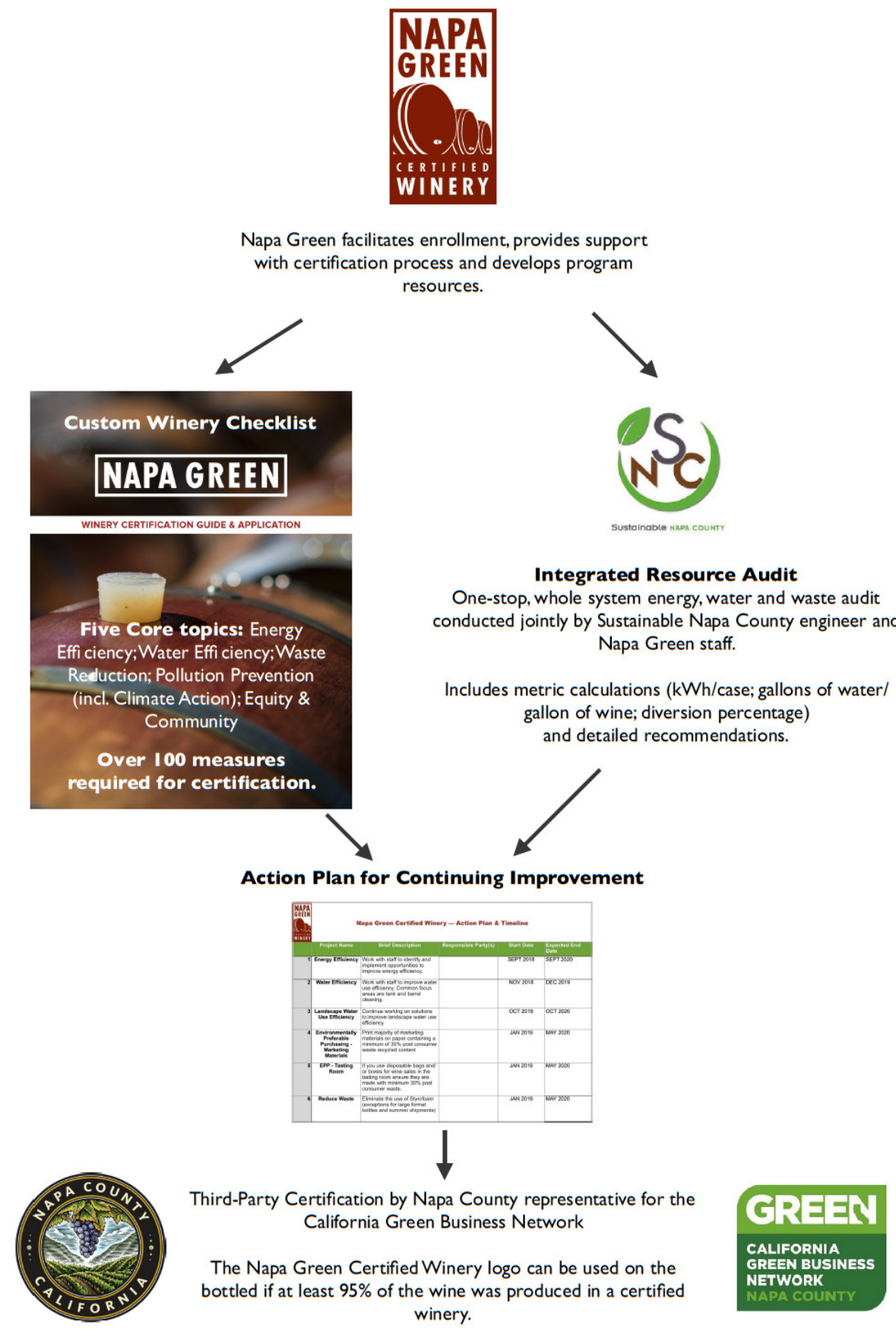

\section{Exhibit 5: Napa Green Winery Certification Process}

through its transition. She knew finding a way for the organization to thrive without the NVV's funding would be a challenge. In early 2020, she hired Megan as a part-time program assistant and relied on her for support for managing marketing communications, strategic planning, and implementing new ideas. As of February 10, 2020, Napa Green had reached more than 80 percent participation in its certification programs (North Bay Business Journal, 2020a).

\section{ANNA BRITTAIN}

Anna grew up in Napa Valley as the only child of a single parent. Throughout her childhood, nature became her refuge. While majoring in political science and environmental studies in college, she became about climate action. Her first job after graduation was working on green building at the American Institute of Architects in Washington, D.C. In 2007, Anna returned to California and began working on the Napa Green Winery program.

For the majority of 2009 to 2013, Anna returned to D.C. and managed the Center for the Management of Ecological Wealth at Resource for the Future. There she supported economists who were doing excellent environmental research, but without any emphasis on translating the work into real world applications. While this frustrated her, it helped her come to an important realization: 
I started to feel like you could actually make more of a difference working locally. So, I moved back home to start a green wine tour business, which I got off the ground but wasn't what I was hoping, and then the Napa Green opportunity came up.

At the helm of Napa Green, Anna spent each day helping wineries and vineyard managers improve their operations to be more sustainable and save money in the long term. Anna was proud to be part of the program and noted, "My work is my passion and mission, and it means a lot to be a part of growing sustainability and environmental stewardship in the special place where I grew up" (North Bay Business Journal, 2020b). She admitted that sometimes it felt like the changes society was making were too incremental, but instead of losing hope, she chose to stay focused on the opportunities (North Bay Business Journal, 2020b). Despite the great progress she saw in the Napa Valley, she believed even more was possible.

\section{OPERATIONS}

Anna worked as a consultant with the Napa Valley Vintners for nearly five years. She managed the growth of the Napa Green program and was the logical choice to step into the role of executive director of the new nonprofit when the time came. Anna worked from home when she was not onsite for meetings, and occasionally used the office space of Sustainable Napa County. In February 2020, Anna brought Megan on as a part-time program assistant for 25 hours a week to assist with overall program operations, and specifically, the Winery certification and enrollment process. While they had contractors and some support from the Napa Valley Vintners, Anna and Megan were essentially the entire internal structure.

With 89 certified wineries, 40 percent of all the certified sustainable wineries in California were within Napa County in early 2020. Anna noted, "Napa County has a pretty outsized impact in terms of the commitment we're making to sustainability in the wine industry right now."

\section{TARGET MARKET}

At the beginning of 2020, there were a little more than 400 physical wineries and nearly 18,616 hectares $(46,000$ acres) of grapes under cultivation in the Napa Valley (CWA Staff, 2019; Napa Valley Vintners, 2019). The Water Board's vineyard Waste Discharge Requirements (WDR) mandated all vineyard properties of 2.02 or more hectares (five acres) in the Napa River watershed have a certified Farm Plan by July 2020. Both Fish Friendly Farming and LandSmart were recognized as facilitating compliance with the WDR, which created a significant added incentive for growers to become certified through either of those programs, and therefore, recognized as Napa Green Land. As of March 2020, over 80 percent of the vineyard acreage in Napa County was enrolled or certified Napa Green Land, adding up to over 14,569 hectares (36,000 acres).

More than 50 of Napa Green's members were comprehensively certified from "soil to bottle"- meaning they had both the Land and the Winery certifications. In 2020, the Napa Valley Vintner's iconic event, Auction Napa Valley, was set to have an emphasis on Napa Green. It even had a committee doing outreach to encourage members to become certified. The auction was originally scheduled for the end of May but was cancelled by March 19, 2020, due to COVID-19. Even still, Napa Green had seen the most winery enrollment in the first quarter of 2020, than they had at the start of any previous year.

Napa Green was helping wineries achieve sustainability and compliance success, resulting in overwhelmingly positive feedback. Cakebread Cellars had doubled its recycling efforts from 48 percent of its total waste to 93 percent (Klearman, 2019). Judd's Hill Winery cut their tank cleaning water use by 66 percent by using a new biodegradable cleaning product specifically designed for the wine industry (Napa Green, 2020b). Yvon Chouinard, environmentalist and founder of Patagonia, even noted, "I've been at this for 30 years, and this is the best, most well-thought-out program I've ever seen" (Napa Green, 2020b).

What was holding back the fence-sitters and naysayers in the valley? Anna explained:

I think a fair number of people who weren't involved yet perceived it as something that was going to cost them money, when in fact we're really helping them improve efficiency and save money. Once that message manages to reach the right person, it will often get someone willing to start looking into it and pursuing it.

Anna noted they had also seen some success with peerto-peer outreach.

\section{AREAS OF DISTINCTION}

The Napa Green holistic certification program made the nonprofit a rarity in the market. As Anna explained:

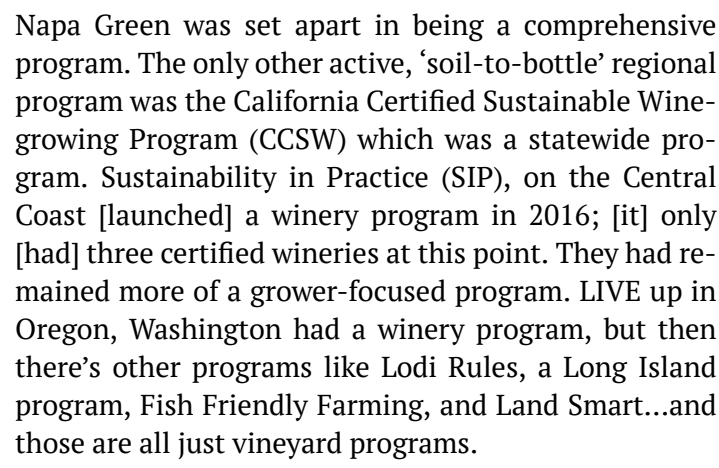

Napa Green was set apart in being a comprehensive program. The only other active, 'soil-to-bottle' regional program was the California Certified Sustainable Winegrowing Program (CCSW) which was a statewide program. Sustainability in Practice (SIP), on the Central Coast [launched] a winery program in 2016; [it] only [had] three certified wineries at this point. They had remained more of a grower-focused program. LIVE up in Oregon, Washington had a winery program, but then there's other programs like Lodi Rules, a Long Island program, Fish Friendly Farming, and Land Smart...and those are all just vineyard programs.

Napa Green was also unique in providing a clear path to compliance with regional environmental standards for vineyards. Members were offered personalized support and a wealth of resources both online and in person.

Moreover, Napa Green had three key elements which further elevated its distinction: its relationship with the Napa Valley Vintners, the Napa [Green] name, and Anna Brittain as the executive director.

\section{Their Relationship with the Napa Valley Vintners}

Having been established by the Napa Valley Vintners, Napa Green would always have historical ties to the NVV. Anna noted that thanks to the Vintners encouraging their members to participate, the first great barrier to adoption 
was considerably lessened. This relationship also provided social proof to the rest of the region and industry as a whole. The NVV supported Napa Green in becoming independent and self-sufficient and had no interest in starting another, similar program. Anna believed Napa Green and the Vintner's relationship was a unique one likely never to be replicated.

\section{The Napa [Green] Name}

The Napa Green name and branding also set the organization apart. Anna and Megan hypothesized that part of its power stemmed from including both the name of the region it specialized in, known for international wine quality, and the word "green" which was widely associated with sustainability. Together, these terms made the brand hard to replicate and provided the organization a distinct advantage in both the regional and international market.

The organization had also provided wineries and vineyards with "Napa Green Certified" signs to put along the highway to promote their Napa Green certifications, and this offered great visibility for the brand as those areas were the most trafficked in the region by visitors and locals alike. Beyond communicating about sustainability on their websites, 11 members had even started including the logo on their wine labels, which when further associated with quality and the Napa name, could lead to increased brand value.

\section{Anna Brittain as executive director}

Anna had extensive knowledge about the organization from having consulted on it for years to helping develop the Winery program itself. She had a deep understanding of the program's intention and intricacies as well as Napa Valley itself, having grown up there. This aspect was key for success in the local region, because: "the very essence of social entrepreneurship is the capability to connect with social and community values, and through adept networking to realize their potential" (Kent \& Anderson, 2003). As part of the community she was serving, this bode well for the organization in the face of new competition. Although times were tough in 2020, having Anna at the helm provided hope for Napa Green's long-term success.

\section{FUTURE OPPORTUNITIES IN THE FACE OF A PANDEMIC}

In April 2020, Anna and Megan were feeling the economic impacts of COVID-19. Planned events, including an inaugural public tasting as well as a member meeting to discuss the nonprofit's transition, were cancelled with no estimate of when they could reschedule. Their entire customer base-local wineries-was also reeling from the crisis. An estimated 30 percent of wines from the region were traditionally sold through tasting rooms and 20 percent to restaurants, and in a matter of weeks both outlets had run dry (McCoy, 2020).

Despite this, the past month had experienced an uptick in interest for sustainability certifications, and they continued to push forward with ongoing recertifications. Perhaps, wineries were focusing on internal projects and improvements since their tasting rooms were closed. In any case, they had scheduled a number of video conferences for recertification audits but needed to wait to schedule onsite visits for newly certifying wineries until late May or June.

In spite of the interest in new certifications and recertifications, finances persisted as their primary concern. With funding from the Napa Valley Vintners stepping down in fiscal year 2021 and 2022, and budget cuts looming, Anna and Megan needed to establish other sources of income as soon as possible. They had made a plan earlier in the year, but the pandemic promised to make it difficult, if not impossible, to secure funding the way they had expected to. Now it was time to rework the business plan and decide where to redouble their efforts to survive. See Exhibit $\mathbf{6}$ for Napa Green's budget.

\section{Establish a Winery Fee Structure}

One way to start bringing in independent income would be to begin formally charging wineries for the certification services already being provided. Anna strongly believed Napa Green needed to establish a Winery Fee Structure because the Pacific Gas and Electric (PG\&E) funding, which had been subsidizing a portion of the Resource Audits, was ending in June. She anticipated charging for audits beginning in July, then rolling out a full Winery Fee Structure in 2021. However, with the extreme financial challenges many wineries faced due to COVID-19, the latter might need to be pushed back. Napa Green also assumed there would be some attrition when certification fees were implemented. While Napa Green was under the umbrella of the NVV, they had subsidized the costs of certification as part of their member's dues to the organization.

Under the proposed Winery Fee Structure, existing wineries in the program would be required to pay licensing fees beginning January 1, 2021. As shown in Exhibit 7, they would receive a 15 percent discount on the first year's fees, and those certified in both programs would receive an additional five percent discount. For existing members due for a full or abbreviated Resource Audit after July 1, 2020, they would need to begin paying full audit fees since PG\&E was no longer subsidizing the audits. Additionally, for corporations with more than one Napa Green Certified Winery, members would receive a stair-stepped five percent discount on licensing fees for each additional certified winery.

\section{Promote sponsorship opportunities}

In early 2020, the Napa Green Sponsorship Program was developed because a few companies had reached out asking how they could get involved, so Anna created a commitment structure as seen in Exhibit 8. Each level offered a variety of benefits for companies to get more exposure to both Napa Green members and its audience. By the end of March 2020, they had secured USD 6,000 and anticipated USD 12,000 by the end of the year with little to no additional outreach efforts.

This option could be pursued with more significant effort from the Napa Green team, although results would be closely associated with the amount of time staff members could commit. With only one full-time and one part-time staff member on board, this posed a challenge-particularly as budget cuts became more likely. 
Exhibit 6: Napa Green Budget

\begin{tabular}{|c|c|c|c|c|c|}
\hline EXPENDITURES & FY 2017 & FY 2018 & FY 2019 & $\begin{array}{l}\text { FY } 2020 \\
\text { (Projected) }\end{array}$ & $\begin{array}{l}\text { FY } 2021 \\
\text { (Proposed) }\end{array}$ \\
\hline $\begin{array}{l}\text { Salaries (Executive Director, Program } \\
\text { Assistant) }\end{array}$ & $\$ 0$ & $\$ 0$ & $\$ 0$ & $\$ 140,640$ & $\$ 109,000$ \\
\hline $\begin{array}{l}\text { Contractors \& Consultants (Programmatic } \\
\text { Contracting, IT Contractor) }\end{array}$ & $\$ 140,000$ & $\$ 140,000$ & $\$ 140,000$ & $\$ 14,100$ & $\$ 0$ \\
\hline $\begin{array}{l}\text { Administrative \& Legal (Employment Tax, } \\
\text { Bookkeeper, Workers Compensation, Liability } \\
\text { Insurance, Reimbursables) }\end{array}$ & $\$ 0$ & $\$ 0$ & $\$ 0$ & $\$ 19,587$ & $\$ 17,787$ \\
\hline Annual 501(c)(3) Insurances & $\$ 4,500$ & $\$ 4,500$ & $\$ 4,500$ & $\$ 4,500$ & $\$ 4,500$ \\
\hline Meetings \& Coworking Space & $\$ 3,443$ & $\$ 3,825$ & $\$ 4,208$ & $\$ 0$ & $\$ 0$ \\
\hline $\begin{array}{l}\text { Marketing \& Advertising (Facebook Ads, } \\
\text { Printed Mat'Is) }\end{array}$ & $\$ 4,000$ & $\$ 4,235$ & $\$ 4,450$ & $\$ 5,218$ & $\$ 5,032$ \\
\hline Sponsorships & $\$ 2,000$ & $\$ 2,000$ & $\$ 2,000$ & $\$ 2,000$ & $\$ 0$ \\
\hline Special Projects \& Events & $\$ 10,000$ & $\$ 12,500$ & $\$ 12,000$ & $\$ 5,000$ & $\$ 5,000$ \\
\hline Website Design \& Email Hosting & $\$ 3,439$ & $\$ 4,047$ & $\$ 4,760$ & $\$ 5,600$ & $\$ 9,000$ \\
\hline Technology & $\$ 0$ & $\$ 0$ & $\$ 0$ & $\$ 2,424$ & $\$ 0$ \\
\hline Miscellaneous & $\$ 680$ & $\$ 680$ & $\$ 680$ & $\$ 4,800$ & $\$ 2,400$ \\
\hline Staff Travel & $\$ 250$ & $\$ 250$ & $\$ 250$ & $\$ 1,500$ & $\$ 1,500$ \\
\hline Est. NVV Staff Value (Average) & $\$ 60,000$ & $\$ 60,000$ & $\$ 60,000$ & $\$ 0$ & $\$ 0$ \\
\hline Total Expenditures & $\$ 228,312$ & $\$ 232,037$ & $\$ 232,848$ & $\$ 205,369$ & $\$ 154,219$ \\
\hline INCOME & FY 2017 & FY 2018 & FY 2019 & $\begin{array}{l}\text { FY } 2020 \\
\text { (Projected) }\end{array}$ & $\begin{array}{l}\text { FY } 2021 \\
\text { (Projected) }\end{array}$ \\
\hline NVV Funding & $\$ 215,000$ & $\$ 215,000$ & $\$ 215,000$ & $\$ 179,188$ & $\$ 90,000$ \\
\hline Sponsorships/Donations & $\$ 0$ & $\$ 0$ & $\$ 0$ & $\$ 18,000$ & $\$ 24,000$ \\
\hline Passport Profits & $\$ 0$ & $\$ 0$ & $\$ 0$ & $\$ 2,000$ & $\$ 0$ \\
\hline Charity Events & $\$ 0$ & $\$ 0$ & $\$ 0$ & $\$ 0$ & \\
\hline Winery Fee Structure & $\$ 0$ & $\$ 0$ & $\$ 0$ & $\$ 0$ & $\$ 96,000$ \\
\hline Total Income & $\$ 215,000$ & $\$ 215,000$ & $\$ 215,000$ & $\$ 199,188$ & $\$ 210,000$ \\
\hline Balance & $-\$ 13,312$ & $-\$ 17,037$ & $-\$ 17,848$ & $-\$ 6,181$ & $\$ 55,782$ \\
\hline
\end{tabular}

Note: All currencies shown in USD. Some financial data points included are estimates.

Source: Information provided by Anna Brittain, Napa Green

\section{Encourage donations}

As a nonprofit 501(c)(3), Napa Green could also accept volunteer labor and tax-deductible donations to help fund the program. While seeking out donors could also be a timeconsuming task, there were a few ways to try and collect this income passively. For instance, no donation function existed on the website. Besides wineries registering for more information on the certification programs, there was no opportunity for interested community members to support the cause online. Social media also provided non-profit business accounts the opportunity to collect donations-a good way to reach younger generations since research showed that online donors tended to be young and generous. Online donations were growing at a rate of around 50 percent per year; hence, establishing a system which en- couraged the community to donate or set up recurring donations could be to their benefit (Heyman \& Brenner, 2019).

\section{Sell winery tasting passes}

In 2020, a company called CellarPass held the majority of the market for promoting regional Passport programs, where a set of participating wineries could offer wine tasting discounts and perks to visitors who had purchased the Passport. In March, Napa Green was in the process of finalizing a Napa Green Tasting Passport, which would include 17 of their member wineries. Tourists could visit and taste at a few certified Napa Green properties and learn more about the program from their ambassadors. Initially, the Passport was set to launch in April 2020 and run through June plus November and December-slower times of year 
when wineries could handle extra traffic.

The appeal of a Passport program was that it would make money to support the nonprofit and educate the winery staff members and visitors about the many facets of winery sustainability. As Anna explained:

\begin{abstract}
I had wanted to do this for a long time, and it was something the Vintners were more on the fence about, but I thought we really had to do it from a fundraising standpoint. I also thought it was really exciting because it was a chance to have a lot more conversations with visitors about sustainable winegrowing. A lot of the visitors still thought sustainable meant organic.
\end{abstract}

She noted that multiple Napa Green wineries did not talk to visitors about their certification because of the hurdle to educate their staff on sustainability to a level where they felt comfortable discussing it. The Napa Green Tasting Passport would require the hospitality staff to gain fluency with the basic facts about Napa Green. To alleviate this concern, Anna and Megan had put together "Napa Green Ambassador" webinars, which they planned to offer on a regular basis beginning in late May 2020.

Initially aiming to launch the pass with 15 to 20 wineries on board in April 2020, Anna had hoped for sales of around 4,000 Passports over the five-month period. This would generate more than USD 250,000 in revenue. Another local passport program, Calistoga's Winter in the Wineries, typically sold 4,000 passports over two months.

However, with the pandemic shutting down tasting rooms valley-wide for months, the launch had to be pushed back and the expected income significantly decreased. Promotions for ticket sales would still be through the CellarPass email list of 300,000 as well as through Napa Green's own efforts. However, with visitation limited, the revenue was hard to predict. There was talk of limited tourism reopening in July with strict protocols around group size, but nothing was certain.

\section{Expand into hotel and restaurant certification}

Since wine tourism dominated the local economic landscape, Napa Green considered developing a Napa Green certification for other businesses in late 2020. In 2018, overnight hotel guests generated nearly 70 percent of the total visitor spending in Napa County, spending an average of USD 446 per guest per day (Visit Napa Valley, n.d.). While the number of visitors day tripping saw growth of only 5.3 percent from 2016 to 2018, overnight visitation in the same period had increased 13.7 percent (Visit Napa Valley, n.d.).

As of 2019 there were 44 businesses in the county certified through the California Green Business Network, and Anna had received interest from a number of businesses seeking the equivalent of a Napa Green certification for their organizations (Napa Green, 2020a). In order to develop and run such a certification, she anticipated needing to hire a consultant and perhaps additional staff. With the way 2020 was already going, she believed this option needed to be pushed to at least 2021 .

\section{DECISION TIME}

As a new nonprofit trying to secure a foothold in the face

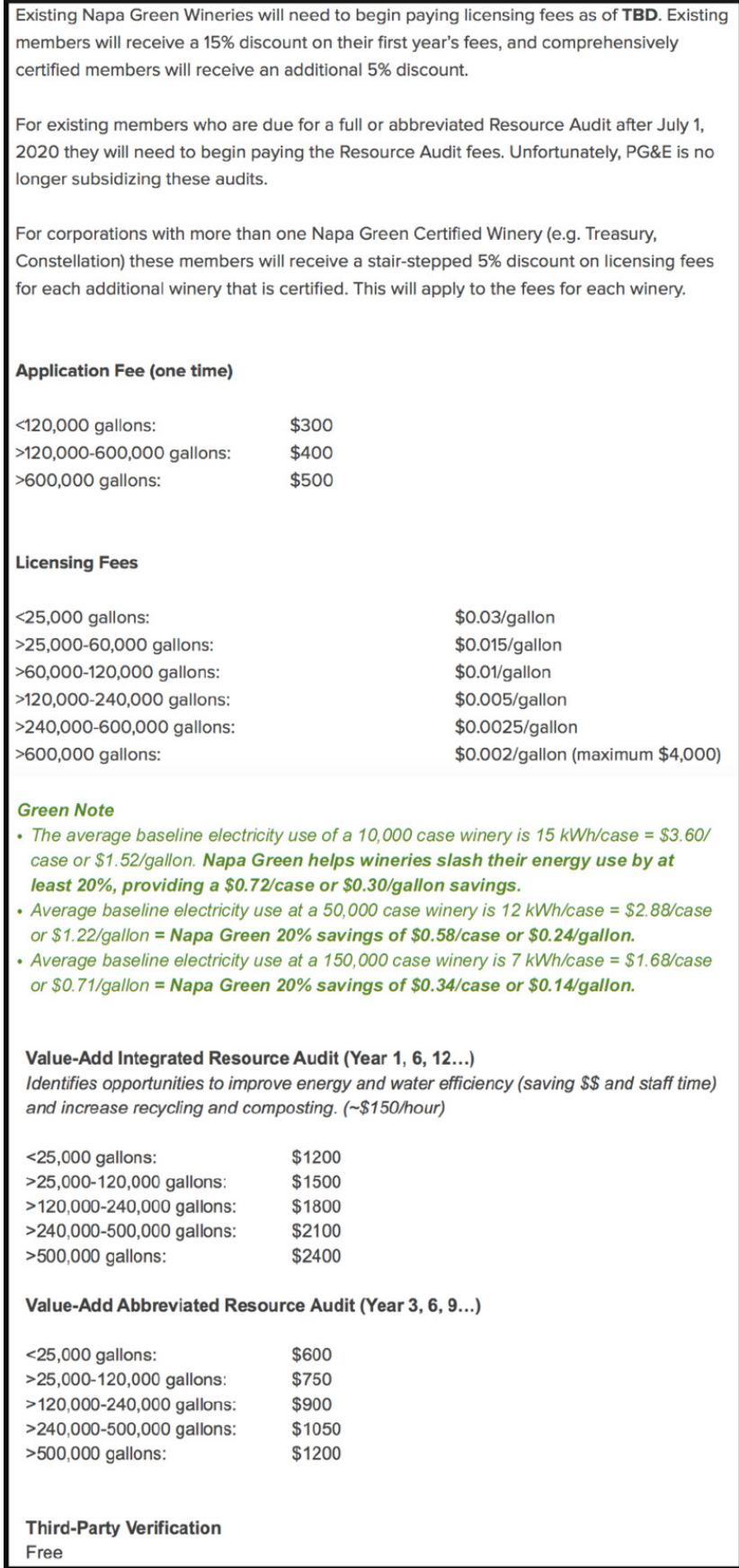

\section{Exhibit 7: Proposed Napa Green Winery Fee} Structure

Source: Anna Brittain, Napa Green

of a global pandemic, Anna and Megan faced a monumental challenge. While they had a variety of options for funding, there was no guaranteed source beyond the NVV for the immediate future. Until they could establish consistent income, budget cuts were never out of the question and they would have to make do with the little they had.

Although interest in the Winery program and recertification was holding steady, their ability to meet with potential members over the next few months was uncertain. They could do remote recertification audits via video conference, but such practices were unsuitable for reviews of newly certifying wineries. Local restrictions hampered their ability to 


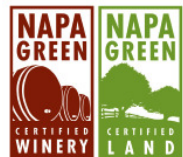

\begin{tabular}{|c|c|c|c|c|}
\hline \multicolumn{5}{|c|}{ Napa Green Sponsorship Tiers } \\
\hline Annual Sponsorship & $\begin{array}{l}\text { Bud Break } \\
\qquad \$ 3,000\end{array}$ & $\begin{array}{l}\text { Veraison } \\
\$ 5,000\end{array}$ & $\begin{array}{l}\text { Harvest } \\
\$ 8,000\end{array}$ & \multirow{10}{*}{$\begin{array}{c}\text { For } \\
\text { sponsorships } \\
\text { above the Tier } \\
\text { IIl level, we can } \\
\text { customize the } \\
\text { partnership } \\
\text { based on the } \\
\text { sponsor/donor } \\
\text { goals. }\end{array}$} \\
\hline Organizational logo on website with live link & $\nabla$ & $\nabla$ & $\nabla$ & \\
\hline Logo in Napa Green e-Newsletter (quarterly) & $\nabla$ & $\nabla$ & $\nabla$ & \\
\hline $\begin{array}{l}\text { One social media spotlight (brief write up and } \\
\text { image) }\end{array}$ & $\nabla$ & & & \\
\hline Two social media spotlights & & $\nabla$ & & \\
\hline Three social media spotlights & & & $\nabla$ & \\
\hline Feature segment in one newsletter & & & $\nabla$ & \\
\hline $\begin{array}{l}\text { Listed as a sponsor of one topic-relevant } \\
\text { workshop for Napa Green members (e.g. } \\
\text { Climate Action Planning) and invitation to } \\
\text { workshop }\end{array}$ & & $\nabla$ & $\nabla$ & \\
\hline $\begin{array}{l}\text { Invitation to biannual Napa Green Awards } \\
\text { Celebration (every } 18 \text { mos. - next event fall } \\
\text { 2020) and partner acknowledgement at event }\end{array}$ & & & $\nabla$ & \\
\hline $\begin{array}{l}\text { Listed as supporting partner on Napa Green } \\
\text { Tasting Passport website (https:// } \\
\text { napagreen.org/napa-green-passport/) }\end{array}$ & & & $\nabla$ & \\
\hline
\end{tabular}

\section{Exhibit 8: Napa Green Sponsorship Tiers}

Source: Anna Brittain, Napa Green

fundraise as they had planned, and they quickly needed to pivot to stay in the black.

Although their future in the midst of COVID-19 was uncertain, one thing was sure: Napa Green needed to find a way to stay financially solvent in order to continue their sustainability work and provide wineries and winegrowers with the most efficient path to compliance. Many now relied on the program for support and guidance, and in its absence the county would be left with a major gap in sustainability leadership. Anna and Megan's only hope was to do a drastic rework of the business plan, reprioritizing their funding strategy for the year. They needed a new plan to survive in the interim as well as long-term-and if possible, impress the NVV to resecure their funding through 2022 in the process. The pandemic would not last forever, but their impact on the valley could if they got this new strategy right.

Submitted: September 15, 2020 PST, Accepted: December 21, 2020 PST 


\section{REFERENCES}

Asimov, E. (2019, October 14). How Climate Change Impacts Wine. The New York Times. https://www.nyti mes.com/interactive/2019/10/14/dining/drinks/climat e-change-wine.html

Barraket, J., Mason, C., \& Blain, B. (2016). Finding Australia's social enterprise sector 2016. Social Traders and Center for Social Impact. http://www.csi.edu.au/m edia/uploads/FASES_2016_full_report_final.pdf

Bauman, M. J., Yuan, J., \& Williams, H. A. (2020). Developing a measure for assessing tourists' empathy towards natural disasters in the context of wine tourism and the 2017 California wildfires. Current Issues in Tourism, 23(19), 2476-2491. https://doi.org/ 10.1080/13683500.2019.1681944

Cheah, J., Amran, A., \& Yahya, S. (2019). Internal oriented resources and social enterprises' performance: How can social enterprises help themselves before helping others? Journal of Cleaner Production, 211, 607-619. https://doi.org/10.1016/i.jcl epro.2018.11.203

Chell, E. (2007). Social Enterprise and Entrepreneurship. International Small Business Journal, 25(1), 5-26. http s://doi.org/10.1177/0266242607071779

Clarke, S. (2019, May 13). Why Some Wineries Are Becoming 'Certified B Corp' - And What That Means. NPR. https://www.npr.org/sections/thesalt/2019/05/1 3/720665348/why-some-wineries-are-becoming-certi fied-b-corp-and-what-that-means

CWA Staff. (2019, September). How Many Wineries Are There In Napa Valley. California Winery Advisor. http s://californiawineryadvisor.com/how-many-wineriesnapa-valley/

Ebrahim, A., Battilana, J., \& Mair, J. (2014). The governance of social enterprises: Mission drift and accountability challenges in hybrid organizations. Research in Organizational Behavior, 34, 81-100. http s://doi.org/10.1016/j.riob.2014.09.001

Fish Friendly Farming. (n.d.). Retrieved May 1, 2020, from https://www.fishfriendlyfarming.org/

Forbes, S. L., Cohen, D. A., Cullen, R., \& Wratten, S. D. (2009). Fountain J. Consumer attitudes regarding environmentally sustainable wine: An exploratory study of the New Zealand marketplace. Journal of Cleaner Production, 17(3), 1195-1199.

Gallenti, G., Troiano, S., Marangon, F., Bogoni, P., Campisi, B., \& Cosmina, M. (2019). Environmentally sustainable versus aesthetic values motivating millennials' preferences for wine purchasing: Evidence from an experimental analysis in Italy. Agricultural and Food Economics, 7(1), 1-16. https://d oi.org/10.1186/s40100-019-0132-X

Heyman, D. R., \& Brenner, L. (2019). Nonprofit management 101: A complete and practical guide for leaders and professionals (pp. 289-404). Wiley.

Jotzo, F., Depledge, J., \& Winkler, H. (2018). US and international climate policy under President Trump. Climate Policy, 18(7), 813-817. https://doi.org/10.108 $\underline{0 / 14693062.2018 .1490051}$
Kent, C. A., \& Anderson, L. P. (2003). Social Capital, Social Entrepreneurship and Entrepreneurship Education. In M. L. Kourilsky \& W. B. Walstad (Eds.), Social Entrepreneurship (pp. 27-45). Senate Hall.

Klearman, S. (2019, December 16). Napa's wine industry to boost environmental sustainability. Napa Valley Register. https://napavalleyregister.com/news/local/n apa-s-wine-industry-to-boost-environmental-sustain ability/article_03936006-115e-5ed5-b18d-527aeaee5c 91.html

Koch, A. (2020, February 9). Winemakers embrace a suite of French technology on the road to greater sustainability. ABC News. https://www.abc.net.au/ne ws/2020-02-10/new-wine-technology-in-tasmania-fo r-greater-sustainability/11947628

LandSmart. (n.d.). Retrieved May 1, 2020, from http://a ndsmart.org/who-we-are/

Lutz, H. (2018, December 7). Napa Valley Vintners earn state's top environmental award. Napa Valley Register. https://napavalleyregister.com/news/local/napa-valle y-vintners-earn-state-s-top-environmental-award/ar ticle_94949fbd-b81b-54ee-8daa-48b2d7cf68a5.html

McCoy, E. (2020, April 2). Struggling Napa Wineries Offer Deep Discounts and Virtual Tastings. Bloomberg. https://www.bloomberg.com/news/article s/2020-04-02/struggling-napa-wineries-offer-deep-di scounts-and-virtual-tastings

Mohan, S. (2014). Viticulture's Promised Land: A Brief History of Napa Valley. SiteLINES: A Journal of Place, 10(1), 17-19. http://www.jstor.org/stable/24889476

Moizer, J., \& Tracey, P. (2010). Strategy making in social enterprise: The role of resource allocation and its effects on organizational sustainability. Systems Research and Behavioral Science, 27(3), 252-266. http s://doi.org/10.1002/sres.1006

Mulkern, A. C. (2020, August 24). Fast-Moving California Wildfires Boosted by Climate Change. Scientific American. https://www.scientificamerican.co $\underline{\mathrm{m} / \text { article/fast-moving-california-wildfires-boosted-b }}$ y-climate-change/

Napa Green. (2020a, March). 2019 Status Update. Napa Green. https://napagreen.org/assets/downloads/pdfs/ 2019-status-update.pdf

Napa Green. (2020b, April). Judd's Hill Cuts Tank Cleaning Water Use by 66 Percent. Napa Green. http s://napagreen.org/judds-hill-cuts-tank-cleaning-wate r-use-by-66-percent/

Napa Valley Vintners. (2019, November 27). Napa Valley Fast Facts. Napa Valley Vintners. https://napavintner s.com/press/docs/napa_valley_fast_facts.pdf

Napa Valley Vintners. (2020, May). History of Wine in the Napa Valley. Napa Valley Vintners. https://napavintne rs.com/napa_valley/history.asp 
Napolitano, M., Potter, S., \& Whyte, D. (2007). Napa River Watershed Sediment TMDL and Habitat Enhancement Plan. California Regional Water Quality Control Board, San Francisco Bay Region. https://ww w.waterboards.ca.gov/water_issues/programs/tmdl/do cs/napariver_sediment/staffreport.pdf

North Bay Business Journal. (2020a, February 10). Napa Green sustainability group for wineries spins off as nonprofit, names top exec. North Bay Business Journal. https://www.northbaybusinessjournal.com/n orthbay/napacounty/10694365-181/napa-green-win e-sustainability

North Bay Business Journal. (2020b, March 3). “Carbon farm plans" among goals for new leader of Napa Valley's winery, vineyard sustainability program. North Bay Business Journal. https://www.northbaybusi nessjournal.com/northbay/napacounty/10759702-18 1/napa-green-wine-vineyard-agriculture-anna-brittai $\underline{\mathrm{n}}$

Powell, M., Gillett, A., \& Doherty, B. (2018). Sustainability in social enterprise: Hybrid organizing in public services. Public Management Review, 21(2), 159-186. https://doi.org/10.1080/14719037.2018.1438 $\underline{504}$

Sirieix, L., \& Remaud, H. (2010, February). Consumer perceptions of eco-friendly vs. conventional wines in Australia [Refereed paper]. 5th International Academy of Wine Business Research Conference, 8-10 February 2010, Auckland (NZ).
Sogari, G., Mora, C., \& Menozzi, D. (2016). Sustainable Wine Labeling: A Framework for Definition and Consumers' Perception. Agriculture and Agricultural Science Procedia, 8, 58-64. https://doi.org/10.1016/j.a aspro.2016.02.008

Szymańska, A., \& Jegers, M. (2016). Modelling Social Enterprises. Annals of Public and Cooperative Economics, 87(4), 501-527. https://doi.org/10.1111/ap ce. 12127

Taber, G. M. (2005). Judgment of Paris: California vs. France and the historic 1976 Paris tasting that revolutionized wine. Scribner.

U.S. Department of Agriculture. (n.d.). Retrieved December 17, 2020, from https://www.usda.gov/topic s/organic

Visit Napa Valley. (n.d.). Travel Research \& Statistics. Visit Napa Valley. Retrieved December 20, 2020, from https://www.visitnapavalley.com/about-us/research/

Visit Napa Valley. (2020, March). 2018 Research Highlights. Visit Napa Valley. https://www.visitnapava lley.com/about-us/research/

Weerawardena, J., McDonald, R. E., \& Mort, G. S. (2010). Sustainability of nonprofit organizations: An empirical investigation. Journal of World Business, 45(4), 346-356. https://doi.org/10.1016/j.jwb.2009.0 $\underline{8.004}$ 